\title{
PENGARUH HAMBATAN KOMUNIKASI ANTARBUDAYA SUKU SUNDA DENGAN NON-SUNDA TERHADAP EFEKTIVITAS KOMUNIKASI
}

\author{
The Influence of Intercultural Communication barriers between Sundanese and Non-Sundanese \\ on Communication Effectiveness \\ Lingga Detia Ananda ${ }^{1)}$ dan Sarwititi Sarwoprasodjo ${ }^{1)}$ \\ ${ }^{1)}$ Departemen Sains Komunikasi dan Pengembangan Masyarakat, Fakultas Ekologi Manusia, Institut \\ Pertanian Bogor, Darmaga Bogor 16680, Indonesia \\ Email: alinggadetia@yahoo.com
}

\begin{abstract}
Cultural diversity in Indonesia has positive and negative impacts. Generally, the positive impact is becoming a nation's wealth that could be a capital to unite the nation. In the other hand, the negative impact which occurred if this cultural diversity can not be integrated and well-organized so it will make misinterpret which is ultimately can lead to conflict and discord nation. This study aims to 1) analyze the communication effectiveness, 2) analyze intercultural communication barriers which occurred between Sundanese and non-Sundanese, 3) analyze the influence of intercultural communication barriers on the communication effectiveness between Sundanese and non-Sundanese. The research is located in Tanjungbaru village, Cikarang Timur district, Bekasi Regency considering the number of migrants with diverse ethnics. The methodology of this research was survey research method (explanatory), with the questionnaire as a research instrument, and supported by qualitative data that obtained through in-depth interviews to the informants. The sampling technique that used was simple random sampling with 40 pairs of friends that have different cultures. The statistical analysis used multiple linear regression test that the result showed that there is a significant influence in intercultural communication barriers on communication effectiveness. The most significant influence on the effectiveness communication of the sequential is psychocultural barriers, cultural barriers and environmental barriers.
\end{abstract}

Keywords: intercultural communication barriers, conflict, effectiveness communication

\begin{abstract}
ABSTRAK
Keragaman budaya di Indonesia memiliki dampak positif dan negatif. Secara umum, dampak positif menjadi kekayaan bangsa yang bisa menjadi modal untuk mempersatukan bangsa. Di sisi lain, dampak negatif yang terjadi jika keragaman budaya ini tidak dapat terintegrasi dan terorganisir dengan baik sehingga akan salah menafsirkan yang akhirnya dapat menimbulkan konflik dan perselisihan bangsa. Penelitian ini bertujuan untuk 1) menganalisis efektivitas komunikasi, 2) menganalisis hambatan komunikasi antar budaya yang terjadi antara Sunda dan non-Sunda, 3) menganalisis pengaruh hambatan komunikasi antarbudaya pada efektivitas komunikasi antara Sunda dan non-Sunda. Penelitian ini berlokasi di Desa Tanjungbaru, Kecamatan Cikarang Timur, Kabupaten Bekasi mengingat jumlah migran dengan beragam etnis. Metodologi penelitian ini adalah metode penelitian survei (explanatory), dengan kuesioner sebagai instrumen penelitian, dan didukung oleh data yang kualitatif yang diperoleh melalui wawancara mendalam dengan informan. Teknik pengambilan sampel yang digunakan adalah simple random sampling dengan 40 pasang teman yang memiliki budaya yang berbeda. Analisis statistik menggunakan uji regresi linier berganda yang hasilnya menunjukkan bahwa ada pengaruh yang signifikan dalam hambatan komunikasi antarbudaya pada efektivitas komunikasi. Pengaruh paling signifikan terhadap efektivitas komunikasi berurutan adalah hambatan psikokultural, hambatan budaya dan hambatan lingkungan.
\end{abstract}

Kata kunci: hambatan komunikasi antar budaya, konflik, efektivitas komunikasi 


\section{PENDAHULUAN}

Indonesia saat ini berpenduduk 238 juta masyarakat dengan keanekaragaman budaya yang cukup majemuk. Menurut Darmastuti (2013) ciri yang menandakan kemajemukan tersebut adalah adanya keberagaman budaya yang tercermin dari perbedaan adat istiadat, bahasa, suku, etnik (bangsa), keyakinan agama, dan lain-lain. Keberagaman budaya ini memiliki dampak positif dan negatif. Secara umum, dampak positifnya yakni keragaman budaya merupakan suatu kekayaan yang dimiliki bangsa Indonesia yang sangat bernilai, dan dapat menjadi modal untuk memajukan serta mempersatukan bangsa, jika dapat terintegrasi dan terorganisir dengan baik. Dampak negatifnya dapat memicu konflik dan terjadi perpecahan bangsa. Contoh kasus konflik di Sampit yaitu konflik antara suku Madura dan Dayak pada Tahun 2001. Kasus ini berawal dari pembunuhan empat anggota keluarga Madura oleh Dayak, karena terjadi kesalahpahaman akibat perbedaan latar belakang budaya. Oleh karena itu, mempelajari budaya masyarakat lain dan belajar berinteraksi dengan masyarakat yang berbeda budaya menjadi suatu kebutuhan dalam proses komunikasi.

Keberagaman budaya ini juga memiliki implikasi terhadap proses komunikasi. Jika dilihat dari aspek komunikasi, keberagaman budaya memiliki keuntungan dan tantangan. Keuntungannya yakni dapat menjadi sarana dalam proses peningkatan wawasan dan cara pandang seseorang di luar budaya dan lingkungannya. Di sisi lain, tantangan yang dihadapi adalah perlunya upaya lebih untuk melakukan komunikasi antarbudaya karena terkadang makna pesan yang diterima oleh komunikan tidak sesuai atau tidak sama dengan makna pesan yang dikirim oleh komunikator yang memiliki perbedaan latar belakang budaya. Perbedaan makna pesan tersebut dapat menyebabkan kesalahpahaman yang terjadi karena adanya perbedaan cara pandang, bahasa, norma, kebiasaan, persepsi dari masing-masing budaya yang dimilikinya. Hasil penelitian Sanjaya (2013) menyatakan bahwa kesalahpahaman yang terjadi karena perbedaan kebiasaan, ketika orang Korea Selatan mengajak orang Indonesia untuk meminum kopi dengan maksud sebagai bentuk pertemanan, orang Indonesia tersebut justru membuatkan secangkir kopi untuk orang Korea Selatan. Kesalahpahaman terjadi ketika orang Korea Selatan ingin mengajaknya pergi keluar untuk meminum kopi sambil berbincang-bincang sebagai bentuk pendekatan pertemanan, namun dimaknai oleh orang Indonesia bahwa orang Korea Selatan ingin disajikan secangkir kopi. Hal ini terjadi karena terdapat perbedaan kebiasaan pada budaya masing-masing. Oleh karena itu, untuk menghindari terjadinya kesalahpahaman, dibutuhkan komunikasi yang efektif di dalamnya.

Hal serupa terjadi di Desa Tanjungbaru, Kecamatan Cikarang Timur, Kabupaten Bekasi. Berdasarkan informasi yang penulis dapatkan dari penduduk setempat, komposisi etnik di desa tersebut cukup beragam karena banyak penduduk pendatang dari berbagai daerah dengan etnik masing-masing, seperti etnik Batak, Jawa, Minangkabau, Betawi dan Madura yang ingin bekerja di pabrik industri yang berada di Kecamatan Cikarang Timur. Penulis juga mendapat informasi dari salah seorang penduduk yang menyatakan bahwa di Desa Tanjungbaru kadang-kadang terjadi kesalahpahaman dalam proses komunikasi. Contohnya adalah kesalahpahaman ketika mereka menggunakan bahasa daerahnya, padahal sedang berbicara dengan pasangan temannya yang berbeda budaya.

Gudykunst dan Kim (1997) menyatakan terdapat empat filter konseptual yang dapat mempengaruhi proses komunikasi dengan orang lain dan dikategorikan ke dalam: Pertama, faktor-faktor budaya (cultural influences on the process) yang menjelaskan mengenai kemiripan dan perbedaan suatu budaya dengan budaya lainnya; Kedua, faktor-faktor sosiobudaya (sosiocultural influences on the process) yaitu merupakan faktor-faktor yang berpengaruh pada proses penataan sosial, dan berkembang berdasarkan interaksi dengan orang lain ketika pola-pola perilaku menjadi konsisten dengan berjalannya waktu; Ketiga, faktor-faktor psikobudaya (psychocultural influences on the process), yaitu faktor-faktor yang mempengaruhi proses penataan pribadi; Keempat, faktor-faktor lingkungan (environmental influences on the process), yaitu faktor-faktor yang berasal dari lingkungan yang dapat mempengaruhi persepsi, emosi, sikap, tingkah laku, dan perasaan kita. 
Berdasarkan penjelasan di atas, penelitian ini bermaksud untuk melihat pengaruh hambatan komunikasi terhadap efektivitas komunikasi antarbudaya berdasarkan dari temuan dan konsep yang dikemukakan oleh Gudykunst dan Kim (1997) mengenai faktor yang mempengaruhi proses komunikasi, penulis mengasumsikan faktor tersebut sebagai suatu hambatan yang terjadi pada proses komunikasi. Diperlukan suatu komunikasi yang efektif untuk mengatasi hambatan tersebut. Gudykunst dan Kim (1997) menyatakan bahwa komunikasi yang efektif bertujuan untuk meminimalisasi kesalahpahaman yang ditandai dengan lahirnya kesamaan makna pesan atas pesan yang telah disampaikan oleh komunikator dan yang diterima oleh komunikan. Oleh karena itu, penelitian ini bertujuan untuk menganalisis pengaruh hambatan komunikasi antarbudaya terhadap efektivitas komunikasi di Desa Tanjungbaru, Kecamatan Cikarang Timur, Kabupaten Bekasi, Provinsi Jawa Barat.

Berdasarkan hal-hal tersebut maka penting untuk menganalisis tentang:

1. Bagaimana efektivitas komunikasi yang terjadi?

2. Apa saja hambatan komunikasi yang terjadi pada masyarakat yang memiliki perbedaan latar belakang budaya?

3. Bagaimana pengaruh hambatan komunikasi antarbudaya terhadap efektivitas komunikasi?

\section{PENDEKATAN TEORITIS}

\section{Komunikasi Antarbudaya}

Gudykunst dan Kim (1997) mengungkapkan komunikasi antarbudaya adalah proses transaksional, simbolik yang melibatkan pemberian makna antara orang-orang dari budaya yang berbeda. Sihabudin (2013) mengatakan bahwa komunikasi antarbudaya adalah komunikasi yang terjadi bila pengirim pesan merupakan anggota dari suatu budaya dan penerima pesannya adalah anggota dari suatu budaya lain. Devito (2009) mengatakan komunikasi antarbudaya merujuk kepada komunikasi antara orang-orang yang memiliki perbedaan budaya, kepercayaan, nilai dan cara berperilaku). Tubbs dan Moss (2008) menyatakan komunikasi antarbudaya adalah komunikasi antara orang-orang yang berbeda budaya. Darmastuti (2013) mengungkapkan komunikasi antarbudaya merupakan proses pengalihan pesan yang dilakukan seseorang melalui saluran tertentu kepada orang lain yang keduanya berasal dari latar belakang budaya yang berbeda dan menghasilkan efek tertentu.

Pakpahan (2013) dalam penelitiannya terkait komunikasi antarbudaya pasangan suami istri berbeda suku, yakni terdapat tiga fungsi komunikasi antarbudaya, dan masing-masing fungsi ini terjadi pada keempat pasangan tersebut. Fungsi pertama, untuk menyatakan identitas sosial yang dinyatakan melalui tindakan berbahasa baik secara verbal dan nonverbal, dari perilaku berbahasa itulah dapat diketahui identitas diri, maupun sosial. Fungsi ini sangat membantu proses pernikahan adat yang akan mereka lakukan. Contohnya karakteristik suku Batak yang cenderung low context menjadi patokan pasangan berbeda etnis untuk berbicara dan bertingkah laku terhadap pasangannya, sehingga mengetahui bagaimana cara berkomunikasi agar tidak terjadi kesalahpahaman di antara mereka mempengaruhi orang untuk lebih berusaha mengarahkan tenaga dalam melaksanakan tugasnya atau mengubah tingkah laku mereka.

\section{Hambatan Komunikasi Antarbudaya}

Proses komunikasi antarbudaya tidak akan berjalan mulus karena terdapat hambatan-hambatan di dalamnya, sehingga dapat menjadi pemicu munculnya konflik antarbudaya. Chaney dan Martin seperti dikutip oleh Sanjaya (2013) mengungkapkan bahwa hambatan komunikasi adalah segala sesuatu yang menjadi penghalang untuk terjadinya komunikasi yang efektif karena adanya perbedaan budaya antara komunikator dan komunikan. Menurut Anugrah dan Kresnowati (2008), hambatan komunikasi adalah halhal yang menyebabkan terdistorsinya pesan yang disampaikan sehingga komunikan tidak dapat menerima pesan yang disampaikan oleh komunikator secara utuh. Merujuk pada buku Communicating with strangers: An approach to intercultural communication yang ditulis oleh Gudykunst dan Kim (1997), penyandian pesan dan penyandian balik pesan merupakan proses interaktif yang dipengaruhi oleh filter-filter konseptual yang dikategorikan ke dalam faktor-faktor budaya (cultural influences on the process), faktor sosiobudaya 
(sosiocultural influences on the process), faktor psikobudaya (psychocultural influences on the process) dan faktor lingkungan (environmental influences on the process).

\section{Efektivitas Komunikasi}

Dalam proses komunikasi, hal yang mutlak diperhatikan adalah tingkat keefektifan komunikasi. Komunikasi dikatakan efektif apabila makna yang ada pada sumber pesan sama dengan makna yang ditangkap oleh penerima pesan. Devito (2009) mengatakan bahwa tidak mungkin untuk dapat berkomunikasi secara efektif tanpa menyadari bagaimana budaya mempengaruhi komunikasi manusia. Selain itu pernyataan Devito didukung oleh Gudykunst dan Kim (1997) yang mengatakan bahwa komunikasi yang efektif akan terjadi apabila kesalahpahaman dapat diminimalisasi.

Efektivitas komunikasi dapat dilihat dari perilaku canggung dan tersinggung. Keefektifan komunikasi akan tercapai jika frekuensi perilaku canggung dan tersinggung ketika proses komunikasi menunjukkan tingkat yang rendah. Hal ini bertujuan agar terciptanya situasi yang mindful yakni merupakan situasi kesalahpahaman yang minimal karena partisipan komunikasi dapat mereduksi hambatan yang timbul karena perbedaan latar belakang budaya dan kedua belah pihak dapat mengelola kecemasan dan ketidakpastian yang terjadi.

Berdasarkan penelitian Azis (2010), rasa ketidaknyamanan dapat terjadi karena adanya suatu rasa ketidakpastian (uncertainty) yang kita miliki terkait perilaku, perasaan, kepercayaan, nilai dan kebiasaan orang lain berbeda etnik dan akhirnya menimbulkan perasaan tersinggung (offend) di antara peserta komunikasi. Rasa cemas (anxiety) dan khawatir dapat timbul ketika seseorang tidak dapat memahami pesan yang disampaikan oleh komunikator dari etnik lain karena kurangnya pengetahuan mengenai bahasa, cara bicara dan budaya etnik lain. Hal ini dapat membuat seseorang merasa canggung ketika berkomunikasi karena tidak mengetahui apa yang harus dilakukan ketika ingin berkomunikasi lawan bicaranya, dengan demikian kesalahpahaman diukur berdasarkan perasaan tersinggung yang timbul ketika berkomunikasi, sedangkan rasa cemas dan khawatir diukur berdasarkan perasaan canggung yang terjadi ketika proses komunikasi berlangsung. Seorang individu itupun akan mungkin merasa takut kehilangan harga diri, dan merasa bahwa identitas sosialnya terancam, pada akhirnya akan merasa bersalah jika berperilaku menyinggung orang asing.

\section{KERANGKA PEMIKIRAN}

Hambatan komunikasi merujuk pada empat filter konseptual Gudykunst dan Kim (1997) yang terdiri dari hambatan budaya (tingkat individualistik-kolektivistik), hambatan sosio budaya (keanggotaan dalam kelompok sosial dan identitas sosial), hambatan psikobudaya (stereotype, etnosentrisme, prasangka), hambatan lingkungan yang dilihat dari sikap terhadap lingkungan fisik, sikap terhadap situasi, sikap terhadap situational norms and rules, dan sikap terhadap lingkungan psikologi. Keempat filter konseptual tersebut dapat mempengaruhi proses komunikasi antarbudaya untuk mencapai efektivitas komunikasi. Gudykunst dan Kim (1997) menyatakan bahwa komunikasi yang efektif memiliki tujuan untuk mengurangi kesalahpahaman, rasa cemas, dan khawatir dari individu yang berkomunikasi.

Dampak dari kesalahpahaman yang terjadi pada komunikasi antarbudaya adalah timbulnya rasa ketidaknyamanan karena adanya suatu rasa ketidakpastian (uncertainty) yang kita miliki terkait perilaku, perasaan, kepercayaan, nilai dan kebiasaan orang lain beda etnik dan akhirnya akan menimbulkan perasaan tersinggung (offend) di antara peserta komunikasi. Rasa cemas (anxiety) dan khawatir dapat timbul ketika seseorang tidak dapat memahami pesan yang disampaikan oleh lawan bicara berbeda etnik, karena kurangnya pengetahuan mengenai bahasa, cara bicara dan budaya etnik lain, dan akhirnya orang tersebut merasa canggung ketika berkomunikasi karena tidak mengetahui apa yang harus dilakukan ketika ingin berkomunikasi lawan bicaranya. Kesalahpahaman diukur berdasarkan perasaan tersinggung, sedangkan rasa cemas dan khawatir diukur berdasarkan perasaan canggung yang ditunjukkan ketika berkomunikasi. Semakin rendah tingkat perasaaan tersinggung dan canggung yang muncul pada saat proses komunikasi 
antara dua orang berbeda budaya, maka semakin efektif komunikasi di antara mereka, begitupun sebaliknya. Berikut kerangka pemikiran penelitian ini.

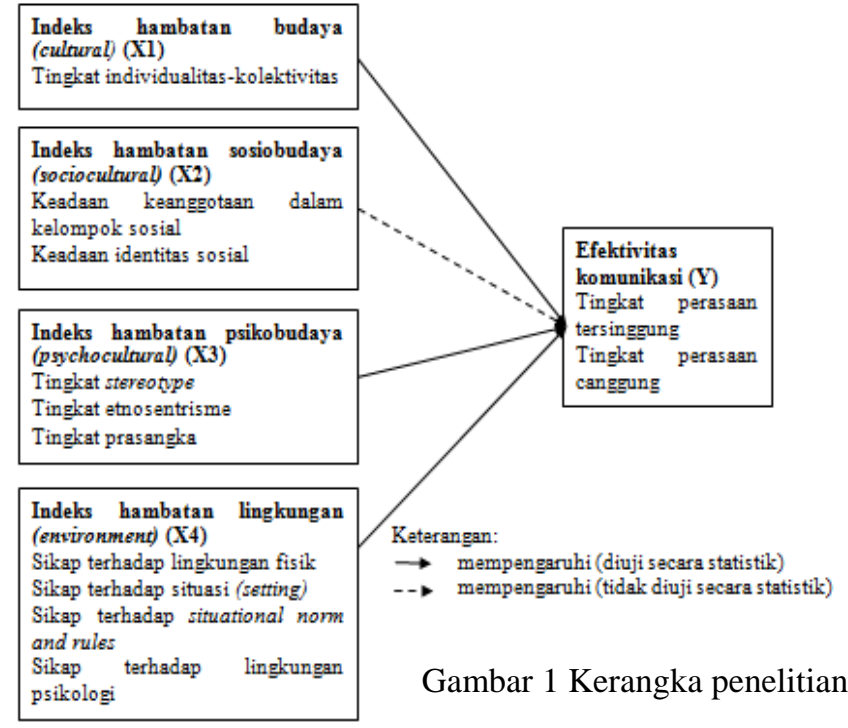

\section{Hipotesis Penelitian}

Hipotesis penelitian ini adalah sebagai berikut:

1. Indeks hambatan budaya mempengaruhi tingkat efektivitas komunikasi antarbudaya

2. Indeks hambatan sosiobudaya mempengaruhi tingkat efektivitas komunikasi antarbudaya

3. Indeks hambatan psikobudaya mempengaruhi tingkat efektivitas komunikasi antarbudaya

4. Indeks hambatan lingkungan mempengaruhi tingkat efektivitas komunikasi antarbudaya

5. Indeks hambatan budaya, psikobudaya, dan lingkungan secara bersamaan mempengaruhi tingkat efektivitas komunikasi antarbudaya.

\section{PENDEKATAN LAPANG}

Penelitian ini menggunakan metode penelitian survei dengan jenis penelitian explanatory. Penelitian ini menggunakan pendekatan penelitian kuantitatif yang didukung oleh data-data kualitatif. Pendekatan kuantitatif dilakukan dengan menggunakan instrumen penelitian berupa kuesioner yang ditujukan kepada responden, dan data kualitatif diperoleh dengan menggunakan pedoman pertanyaan yang ditujukan kepada informan. Lokasi penelitian dipilih secara purposive, yakni di Desa Tanjungbaru, Kecamatan Cikarang Timur, Kabupaten Bekasi, Provinsi Jawa Barat. Alasan pemilihan lokasi ini karena berdasarkan informasi yang diperoleh dari informan, di wilayah Desa Tanjungbaru telah banyak dibangun berbagai macam pabrik industri, sehingga banyak pendatang dengan berbagai suku non-Sunda dari luar daerah untuk menetap dan mencari pekerjaan di pabrik industri sekitar desa ini. Kegiatan penelitian ini dilaksanakan dalam jangka waktu enam bulan terhitung mulai bulan Juni 2014 sampai dengan Januari 2015.

Teknik penarikan sampel yang digunakan yakni dengan terlebih dahulu membuat kerangka sampling berupa daftar nama pendatang yang terdiri dari suku non-Sunda sebanyak 71 orang (terlampir) di Dusun 1 Desa Tanjungbaru dengan pertimbangan bahwa jumlah pendatang (suku non-Sunda) yang menetap dalam kurun waktu 5 tahun terakhir berada di Dusun 1. Unit analisis penelitian ini adalah individu. Teknik penarikan sampel yang digunakan adalah probability sampling agar populasi mempunyai kesempatan yang sama untuk dipilih sebagai sampel (Singarimbun dan Effendi 1989), berupa simple random sampling, yakni mengambil sampel dari anggota populasi dengan menggunakan acak tanpa memperhatikan strata dalam populasi tersebut. Pengambilan sampel secara acak ini dibantu oleh program komputer dengan software Microsoft Excel 2007. Jumlah sampel yang digunakan sebanyak 40 pasang pertemanan berbeda suku yang telah terjalin maksimal 5 tahun, dengan usia masing-masing responden berkisar antara 17-45 tahun. Hal ini 
dilakukan untuk menjamin terpenuhinya jumlah 40 pasangan pertemanan karena jumlah warga suku nonSunda lebih sedikit dari jumlah warga suku Sunda. Informan dipilih secara purposive (sengaja) diwawancarai dengan menggunakan panduan pertanyaan, terdiri atas pejabat pemerintahan desa (kepala pemerintahan desa, ketua BPD), ketua RT, ibu RK, dan beberapa warga suku Sunda dan non-Sunda.

Data penelitian juga diperoleh dengan melakukan wawancara mendalam kepada informan terkait dengan kondisi umum komunikasi antara warga suku Sunda dan non-Sunda serta digunakan sebagai instrumen pendekatan kualitatif dan sumber informasi lain terkait dengan variabel-variabel yang akan diuji pada penelitian ini. Data sekunder yang mendukung penelitian ini diperoleh melalui informasi tertulis atau dokumen yang dapat mendukung kelengkapan kebutuhan data.

Data penelitian secara statistik diolah dengan dibantu program komputer dengan software (perangkat lunak) bernama Statistical For Social Science (SPSS) versi 21.0 for windows, yaitu dengan menggunakan uji regresi berganda.

\section{Gambaran Umum Lokasi Penelitian}

Desa Tanjungbaru memiliki jumlah penduduk sebanyak 15.067 jiwa, dengan jumlah laki-laki sebanyak 7.704 jiwa dan jumlah perempuan sebanyak 7.363 jiwa. Penduduk tersebut tersebar di 3 dusun, yakni Dusun 1 yang terdiri dari 6 RT dan 3 RW, Dusun 2 yang terdiri dari 9 RT 5 RW, dan Dusun 3 yang terdiri dari 5 RT dan 3 RW. Banyaknya jumlah penduduk yang terdiri dari penduduk pribumi maupun pendatang ini, sangat memungkinkan komunikasi antarbudaya penduduk pribumi dan pendatang dapat terjadi. Pada awalnya wilayah Kabupaten Bekasi, Kecamatan Cikarang Timur, khususnya di Desa Tanjungbaru, masyarakat yang tinggal dan menetap di desa tersebut hanyalah orang pribumi dengan suku asli yaitu suku Sunda. Menurut keterangan dari informan, sekitar Tahun 1980an-1990an penduduk Desa Tanjungbaru semakin bertambah dengan kehadiran penduduk pendatang dari kota-kota lain. Pada saat itu, kebanyakan pendatang yang datang bertujuan untuk membangun usaha seperti pabrik industri.

\section{HASIL PENELITIAN}

\section{Efektivitas Komunikasi}

Berdasarkan hasil survei terhadap 40 pasang pertemanan responden antara suku Sunda dan suku non-Sunda (Jawa, Madura, Batak, Minangkabau, Betawi) dalam kehidupan ketetanggaan, didapatkan sebaran nilai seperti yang disajikan pada Tabel 1 berikut.

Pada Tabel 1 diperoleh nilai rata-rata skor total efektivitas komunikasi (Y) sebesar 96.83 dengan standar deviasi sebesar 11.67, nilai skor total minimum adalah 71.00 dan nilai skor total maksimum adalah 121.00. Nilai rata-rata skor total yang didapat adalah 96.83 dari skor total sebesar efektivitas komunikasi (Y) 128.00 dan persentase hambatan sebesar 67.53. 
Tabel 1 Sebaran nilai rata-rata, skor total minimal, skor total maksimal, dan presentase variabel pengaruh (hambatan budaya, psikobudaya, lingkungan) dan variabel terpengaruh (efektivitas komunikasi)

\begin{tabular}{|c|c|c|c|c|c|c|}
\hline No & Variabel & Subvariabel & $\begin{array}{r}\text { Rata- } \\
\text { rata }\end{array}$ & $\begin{array}{r}\text { Skor } \\
\text { totalmin }\end{array}$ & $\begin{array}{r}\text { Skor } \\
\text { totalmax }\end{array}$ & Persentase \\
\hline \multirow[t]{2}{*}{1} & Efektivitas & & & & & \\
\hline & komunikasi $(Y)$ & & 96.83 & 32.00 & 128.00 & 67.53 \\
\hline \multirow[t]{2}{*}{2} & Hambatan & Individualistik & & & & \\
\hline & Budaya (X1) & (X1A) & 40.83 & 16.00 & 64.00 & 51.72 \\
\hline \multirow[t]{5}{*}{3} & Hambatan & & & & & \\
\hline & & Stereotype (X3A) & $\begin{array}{l}63.33 \\
18.84\end{array}$ & $\begin{array}{r}28.00 \\
8.00\end{array}$ & $\begin{array}{r}112.00 \\
32.00\end{array}$ & $\begin{array}{l}42.06 \\
45.16\end{array}$ \\
\hline & & Etnosentrisme & 10.04 & & & 47.10 \\
\hline & & (X3B) & 13.64 & 6.00 & 24.00 & 42.44 \\
\hline & & Prasangka $(\mathrm{X} 3 \mathrm{C})$ & 30.85 & 16.00 & 56.00 & 40.11 \\
\hline \multirow[t]{6}{*}{4} & Hambatan & & & & & \\
\hline & Lingkungan (X4) & & 87.38 & 36.00 & 144.00 & 47.57 \\
\hline & & $\begin{array}{l}\text { Lingkungan Fisik } \\
\text { (X4A) }\end{array}$ & 20.08 & 8.00 & 32.00 & 50.33 \\
\hline & & Situasi (X4B) & 33.93 & 14.00 & 56.00 & 47.46 \\
\hline & & $\begin{array}{l}\text { Situational Norms } \\
\text { and Rules (X4C) } \\
\text { Lingkungan }\end{array}$ & 16.61 & 7.00 & 28.00 & 45.76 \\
\hline & & psikologi (X4D) & 16.76 & 7.00 & 28.00 & 46.47 \\
\hline
\end{tabular}

Hasil tersebut menunjukkan bahwa efektivitas komunikasi yang terjadi memiliki kecenderungan yang tinggi, tetapi masih belum mencapai angka maksimal karena masih terdapat hambatan-hambatan yang dirasakan oleh pasangan pertemanan berbeda budaya. Hal ini terjadi karena perbedaan simbol-simbol yang digunakan oleh suatu budaya tidak jarang membawa dampak perbedaan pemaknaan terhadap simbol-simbol sehingga perbedaan persepsi terkadang masih terjadi. Jalinan pertemanan yang belum terlalu lama dengan intensitas pertemuan mereka yang tidak terlalu tinggi juga menjadi salah satu alasan kesulitan dalam memahami simbol-simbol budaya satu sama lain. Intensitas pertemuan yang tidak terlalu tinggi ini karena baik suku Sunda maupun non-Sunda (Jawa, Madura, Batak, Minangkabau, dan Betawi) memiliki kepentingan masing-masing. Selain itu, mayoritas suku non-Sunda yang merupakan pendatang memang sibuk dengan pekerjaan yang mereka lakukan disana. Hal-hal tersebut yang masih membuat mereka merasa canggung ketika ingin memulai pembicaraan atau tersinggung ketika terjadi salah persepsi dari pesan yang disampaikan oleh lawan bicaranya.

\section{Hambatan Komunikasi Antarbudaya}

Kondisi efektivitas komunikasi yang belum maksimum terjadi karena masih terdapat hambatan pada proses komunikasi antarbudaya suku Sunda dan non-Sunda (Jawa, Madura, Batak, Minangkabau, dan Betawi).

\section{Hambatan Budaya}

Pada Tabel 1 diperoleh rata-rata skor total hambatan budaya (X1) dengan dimensi individualistik sebesar 40.84 dari skor total maksimum hambatan budaya sebesar 64.00 dan persentase hambatan sebesar 51.72. Hasil tersebut menunjukkan bahwa hambatan budaya memiliki nilai hambatan yang cenderung tinggi terkait hambatan individualistik mengenai orientasi personal, yakni sikap individu yang hanya memprioritaskan pada kepentingan/keperluan diri sendiri. Orientasi personal merupakan aspek dimensi individualistik yang terjadi paling tinggi pada pasangan pertemanan berbeda budaya suku Sunda dan nonSunda. Hal ini dibuktikan oleh pengakuan responden yang menggambarkan lebih mendahulukan kepentingan pribadinya dibandingkan pasangan temannya.

"Iya sih, kalau ada info raskin gitu mah aku kasih tau ke mama dulu, atau kalau misalnya kayak kemarin ada pembagian daging kurban tuh, langsung bilang mama biar kita ga keabisan, abis kadang suka pada doubledouble kupon orang-orang lain" (RFL, 24 th, Pendatang-Betawi) 


\section{Hambatan Sosiobudaya}

Hambatan sosiobudaya yang terjadi pada komunikasi pasangan pertemanan berbeda budaya yang terjadi fokus pada identitas sosial, terutama pada penggunaan bahasa sebagai bentuk dari identitas etnik. Perbedaan bahasa yang digunakan dalam suasana informal biasanya menggunakan bahasa ibu/bahasa daerah asal mereka datang.

Menurut beberapa informan, kendala komunikasi yang sering terjadi adalah kendala bahasa yang terkadang menjadi suatu hambatan yang dapat mengakibatkan kesalahan persepsi dan kesalahpahaman dalam bertukar informasi. Bahasa berperan penting dalam menolong seseorang membentuk dan mempertahankan identitas etnik mereka. Seperti ketika responden NHR yang merupakan warga suku Betawi tidak mengerti ketika teman suku Sunda nya menggunakan bahasa Sunda.

"Bengong aja dah kita mah kan jadinya pas dia kalo lagi ngomong bahasa Sunda, lah orang kita kaga ngarti kan dia ngomong apa, suka bet tuh kayak gitu, yaudah saya bagenin aja, ya orang kita nggak ngerti hehe.

Tapi paling kalo penasaran ya saya nanya itu apa artinya." (NHR, 37 th, Pendatang-Betawi)

\section{Hambatan Psikobudaya}

Pada Tabel 1 diperoleh rata-rata skor total hambatan psikobudaya (X3) sebesar 63.32 dari skor total maksimum hambatan psikobudaya sebesar 112.00 dan persentase hambatan sebesar 42.06. Hasil tersebut menunjukkan bahwa hambatan psikobudaya memiliki nilai hambatan yang cenderung lebih rendah dibandingkan dengan hambatan budaya dan hambatan lingkungan. Jika dipaparkan secara spesifik, hambatan psikobudaya terbagi menjadi 3 dimensi yakni dimensi stereotype (X3A), etnosentrisme (X3B), dan prasangka $(\mathrm{X} 3 \mathrm{C})$.

\section{a. Stereotype}

Pada Tabel 1 diperoleh rata-rata skor total hambatan stereotype (X3A) sebesar 18.84 dari skor total maksimum hambatan psikobudaya sebesar 32.00. dan persentase hambatan sebesar 45.16. Hasil tersebut menunjukkan bahwa hambatan stereotype (X3A) cenderung rendah. Berdasarkan penelitian yang dilakukan, pada dasarnya memang mereka memiliki stereotype terhadap pasangan teman yang berbeda suku, namun hal tersebut tidak menjadi suatu hambatan yang berarti karena masing-masing saling menjaga perasaan pasangan temannya dalam berinteraksi sehari-hari, seperti penuturan berikut:

“...memang kalau stereotype ya ada yah buat saya pribadi, tapi kalau udah kenal dan dia orangnya asik dan bisa beradaptasi mah enak aja, lagian kalau dia yang tidak bisa beradaptasi dia yang rugi sendiri, kan dia hidup di sini butuh bantuan orang, misalnya butuh pasir, butuh apa gitu kalau udah kenal mah kan enak" (JNN, 32 th, Ketua BPD).

\section{b. Etnosentrisme}

Pada Tabel 1 diperoleh rata-rata skor total hambatan etnosentrisme (X3B) sebesar 13.64 dari skor total hambatan etnosentrisme sebesar 24.00 dan persentase hambatan sebesar 42.44. Hasil tersebut menunjukkan bahwa hamb atan etnosentrisme (X3B) cenderung rendah. Berdasarkan penelitian yang dilakukan, etnosentrisme yang terjadi di Desa Tanjungbaru tidak mencuat secara nyata. Hambatan cenderung tidak tinggi dan tidak rendah. Hal tersebut terjadi karena responden merasa bahwa masing-masing suku memiliki karakter, sifat, dan peraturan pada sukunya. Jadi, tidak dapat dengan mudah dikatakan bahwa pasangan temannya harus mengikuti standar nilai dan norma yang berada dalam sukunya, namun ia tetap menjadikan sukunya sebagai suatu kebanggaan bagi dirinya dalam kelompok sosialnya.

\section{c. Prasangka}

Pada Tabel 1 diperoleh rata-rata skor total hambatan prasangka sebesar 30.85 dari skor total hambatan prasangka (X3B) sebesar 56.00 dan persentase hambatan sebesar 40.11. Hasil tersebut menunjukkan bahwa hambatan prasangka cenderung rendah. Hal ini dapat disimpulkan karena usia pertemanan yang terbilang belum terlalu lama, ditambah dengan intensitas pertemuan yang tidak terlalu tinggi, belum membuat 
masing-masing pasangan pertemanan mengenal satu sama lain secara detil. Selain itu juga disebabkan oleh responden yang memiliki kecenderungan berpikir negatif dengan yang dilakukan temannya.

\section{Hambatan Lingkungan}

Pada Tabel 1 diperoleh diperoleh rata-rata skor total hambatan lingkungan (X4) adalah 87.38 dari skor total hambatan lingkungan (X4) sebesar 144.00 dan persentase hambatan sebesar 47.57. Hasil tersebut menunjukkan bahwa hambatan lingkungan cenderung tinggi. Hal itulah yang menyebabkan adanya persepsi responden mengenai pasangan teman responden yang berupa perasaan negatif. Jika dipaparkan secara spesifik, hambatan lingkungan terbagi menjadi empat dimensi yakni dimensi lingkungan fisik (X4A), situasi (X4B), situational norms and rules (X4C), dan lingkungan psikologi (X4D). Berdasarkan Tabel 1 pada hambatan lingkungan yang mempengaruhi proses komunikasi dapat dilihat dari empat dimensi, yaitu lingkungan fisik, situasi, situational norms and rules dan lingkungan psikologi. Lingkungan dimana tempat interaksi antara pasangan pertemanan berbeda budaya ini akan mempengaruhi proses komunikasi.

\section{a. Lingkungan fisik}

Pada Tabel 1 diperoleh rata-rata skor total hambatan lingkungan fisik (X4A) sebesar 20.08 dari skor total hambatan lingkungan fisik (X4A) sebesar 32.00 dan persentase hambatan sebesar 50.33. Hasil tersebut menunjukkan bahwa hambatan lingkungan fisik memiliki nilai hambatan yang cenderung tinggi dibandingkan dengan dimensi hambatan lingkungan yang lain. Pada hambatan ini terjadi ketika keadaan letak geografis membentuk budaya masing-masing. Perbedaan letak geografis dan juga kepadatan penduduk baik yang ada di Desa Tanjungbaru maupun di tempat asal para pendatang suku non-Sunda dapat mempengaruhi bagaimana cara berkomunikasi. Misalnya pemukiman asli orang Batak yang tinggal di daerah pegunungan, rumah berjauhan dan banyak dilalui oleh angin yang kencang, membuat suatu budaya komunikasi orang Batak yang harus berbicara dengan volume suara keras agar terdengar oleh lawan bicaranya. Berbeda dengan pulau Jawa, terlebih daerah Desa Tanjungbaru yang kini mulai padat penduduknya, awalnya mungkin tidak terbiasa atas perbedaan volume suara pada saat berkomunikasi yang mempengaruhi bagaimana cara kita berbicara dengan orang lain. Akan tetapi, seiring makin banyaknya pendatang suku non-Sunda dari daerah Sumatera yang datang, maka warga pribumi pun sudah tidak asing lagi jika berbicara dengan orang Medan yang menggunakan volume suara keras.

"Kaget saya mbak awalnya dia kalo ngomong kenceng banget saya awalnya mikir ini padahal cewek ngga bisa pelan-pelan gitu,ngga ada lembut-lembutnya, rada cablak apa adanya juga kan, dulu sih pas awal kenal ya agak nggak enak gitu, tapi saya paham si, tau dia ya sebenernya maksutnya nggak gitu, cuma emang kalo ngomong kenceng banget gitu" (FAS, 26 th, Pribumi-Sunda).

Selain letak geografis, penataan ruangan juga menjadi salah satu hal yang mempengaruhi proses komunikasi (Gudykunst dan Kim 1997). Berdasarkan keterangan yang didapat dari responden suku Jawa, jika di rumahnya hendak mengadakan acara atau hanya sekedar berkumpul dengan ibu-ibu, ia selalu menyiapkan tempat di bagian depan ruang tamu yang bersatu dengan usaha warungnya, sedangkan ruangan bagian dalam ditutup dengan kain gorden. Beliau selalu menerima tamu di ruangan tersebut, karena menurutnya ruangan bagian dalam adalah ruangan pribadi untuk anak dan suaminya saja.

\section{b. Situasi}

Pada Tabel 1 diperoleh rata-rata skor total hambatan situasi (X4B) sebesar 33.93 dari skor total hambatan situasi sebesar 56.00 dan persentase hambatan sebesar 47.46. Hasil tersebut menunjukkan bahwa hambatan situasi memiliki nilai hambatan yang cenderung rendah. Hambatan situasi yang terjadi yakni suatu kondisi yang dapat mempengaruhi proses komunikasi yang berlangsung, seperti setting waktu dan tempat, tujuan berkomunikasi saat itu (materi yang didiskusikan), partisipan komunikasi, dan hubungan antara partisipan. Secara keseluruhan hambatan situasi yang paling besar yakni pada aspek partisipan komunikasi, yaitu pasangan temannya sendiri. Terkadang terdapat sifat pada pasangan temannya yang sebenarnya tidak membuat responden untuk tertarik untuk berkomunikasi lebih lama. Sikap responden tersebut terbentuk sesuai tingkat responden menyukai lawan bicaranya. Hal tersebut dirasakan oleh salah satu responden, ketika pasangan teman suku Sunda ikut campur dalam mengomentari urusan keluarganya, 
NHR tetap memendam rasa kesalnya, hal tersebut kadang membuatnya agak sedikit "malas" untuk berkomunikasi, terutama membicarakan masalah pribadi.

“... tapi tetep aja gitu, saya ngerasanya dia terlalu ikut campur banget masalah keluarga saya, mentangmantang dia lebih tua gitu, abisnya kadang keseringan banget gitu neng ikut campurnya, ya kalo sekali dua kali bagen dah saya gapapa yah. Emangnya aja dia suka gitu. Tapi itu dulu sih, sekarang sih saya udah biasa aja ke dianya" (NHR, 37 th, Pendatang-Betawi).

\section{c. Situational norms and rules}

Pada Tabel 1 diperoleh rata-rata skor total hambatan situasional norms and rules (X4C) sebesar 16.61 dari skor total hambatan situasional norms and rules (X4C) sebesar 28.00 dan persentase hambatan sebesar 45.76. Hasil tersebut menunjukkan bahwa hambatan situasional norms and rules memiliki nilai hambatan yang cenderung rendah. Hal ini terjadi karena pada dasarnya masing-masing pasangan pertemanan tidak memiliki perbedaan norma dan aturan yang terbentang jauh, seperti penuturan salah satu responden berikut:

"Kalau hambatan kayak norma atau aturan sih nggak ada yah, sama aja pada dasarnya, cuma memang ada beberapa hal aja yang beda, tapi jadi lucu. Misalnya kalau orang Sunda kan setiap bertamu tuh selalu salaman, murah senyum kan senyum terus, udah gitu selalu menawarkan makanan atau suguhan, nah kalau di adat saya kayak begituan ya dianggap seperlunya aja, nggak perlu berlebihan salaman-salaman terus. Waktu itu saya juga pernah makan bareng dia, terus saya sendawa, kalau di adat saya sih biasa aja, tapi katanya di adat dia itu dianggap tidak baik, kalau saya sendawa dia suka bilang goreng patut" (NRH, 24 th, PendatangBatak).

Tabel 2 Nilai signifikansi, nilai koefisien, dan arah pengaruh variabel pengaruh terhadap variabel terpengaruh berdasarkan hasil uji statistik analisis regresi linier berganda

\begin{tabular}{llrrr}
\hline No & Variabel & B & Sig. & Arah pengaruh \\
\hline 1 & Konstanta & 192.202 & 0.000 & \\
2 & Budaya (X1) & -0.420 & 0.000 & Negatif \\
3 & Psikobudaya (X3) & -0.826 & 0.000 & Negatif \\
4 & Lingkungan (X4) & -0.296 & 0.000 & Negatif \\
5 & Nilai signifikasi uji F & & 0.000 & Negatif \\
6 & Nilai koefesien determinasi & & 0.800 & \\
\hline
\end{tabular}

d. Lingkungan Psikologi

Pada Tabel 1 diperoleh rata-rata skor total sebesar 16.76 dari skor total hambatan lingkungan psikologi (X4D) sebesar 28.00 dan persentase hambatan sebesar 46.76. Hasil tersebut menunjukkan bahwa hambatan lingkungan psikologi memiliki nilai hambatan yang cenderung rendah. Akan tetapi, masih ada hambatan yang terjadi pada responden ketika memang pintu rumah pasangan temannya selalu tertutup, hal tersebut memberi kesan kepada responden bahwa pasangan temannya merupakan orang yang tertutup dan tidak mau diganggu, seperti penuturan responden berikut:

“...rumahnya emang keseringan ketutup teh, jarang keluar juga, paling keluar kalau mau kerja atau ada urusan aja, jadi saya juga kan jadi segen gitu ya teh kalau mau main, ya tapi kalau mau kesana sih ketokketok aja, atau sms dulu gitu dia ada di rumah apa engga. Emang orangnya rada tertutup sih teh, tapi kalo buat ngobrol sehari-hari mah negor ya negor gitu nyapa." (ASH, 20 th, Pribumi-Sunda)

\section{Pengaruh Hambatan Komunikasi Antarbudaya terhadap Efektivitas Komunikasi}

Hambatan komunikasi yang merujuk pada empat filter konseptual Gudykunst dan Kim (1997) diduga mempengaruhi efektivitas komunikasi antarbudaya secara signifikan. Hasil uji statistik regresi linier berganda menunjukkan bahwa hambatan komunikasi memiliki pengaruh yang signifikan terhadap efektivitas komunikasi antarbudaya disajikan pada Tabel 2.

Hasil uji regresi koefisien determinasi ( $R$ Square) yang dilakukan menunjukkan hasil bahwa hambatan komunikasi memiliki pengaruh yang signifikan terhadap efektivitas komunikasi. Berdasarkan Tabel 2 diperoleh nilai $R$ Square yang menunjukan angka 0.800. Angka koefisien determinasi ketiga variabel tersebut tersebut memiliki arti bahwa pengaruh hambatan budaya (X1), hambatan psikobudaya (X3) dan 
hambatan lingkungan (X4) memberikan sumbangan sebesar 80.0 persen terhadap perubahan efektivitas komunikasi (Y), dan sisanya sebesar 20.0 persen merupakan variabel lain.

Berdasarkan hasil Tabel 2, variabel hambatan budaya (X1), psikobudaya (X3), dan lingkungan (X4) memiliki pengaruh yang signifikan terhadap variabel efektivitas komunikasi (Y) dengan masing-masing arah pengaruh negatif. Hal tersebut menunjukkan bahwa semakin tinggi hambatan budaya (X1), psikobudaya (X3), dan lingkungan (X4) yang terjadi di antara partisipan komunikasi, maka semakin rendah efektivitas komunikasi (Y) yang terjadi, begitupun sebaliknya, semakin rendah hambatan budaya (X1) yang terjadi di antara partisipan komunikasi, maka semakin tinggi efektivitas komunikasi (Y).

\section{Pengaruh Hambatan Budaya terhadap Efektivitas Komunikasi}

Berdasarkan Tabel 3, variabel hambatan budaya (variabel X1) berpengaruh terhadap variabel efektivitas komunikasi (variabel Y) dengan arah pengaruh negatif. Hal tersebut menunjukkan bahwa semakin tinggi hambatan budaya (X1) yang terjadi di antara partisipan komunikasi, maka semakin rendah efektivitas komunikasi (Y) yang terjadi, begitupun sebaliknya, semakin rendah hambatan budaya (X1) yang terjadi di antara partisipan komunikasi, maka semakin tinggi efektivitas komunikasinya (Y).

Tabel 3 Nilai koefisien, nilai signifikansi, dan arah pengaruh berdasarkan hasil uji statistik variabel pengaruh (Individualistik, stereotype, etnosetrisme, prasangka, lingkungan fisik, situasi, situasional norms and rules, dan lingkungan psikologi) dan variabel terpengaruh (efektivitas komunikasi)

\begin{tabular}{|c|c|c|c|c|c|}
\hline No & Variabel & Subvariabel & B & Sig. & Arah pengaruh \\
\hline 1 & \multicolumn{2}{|c|}{ Efektivitas komumikasi (Y) } & 186.162 & 0.000 & \\
\hline 2 & Budaya (X1) & Individualistik (X1A) & -0.277 & 0.005 & Negatif \\
\hline 3 & & Stereotype (X3A) & -0.862 & 0.000 & Negatif \\
\hline 5 & Psikobudaya (X3) & $\begin{array}{l}\text { Prasangka (X3C) } \\
\text { Lingkungan Fisik }\end{array}$ & -0.587 & 0.001 & Negatif \\
\hline 6 & & (X4A) & -0.676 & 0.008 & Negatif \\
\hline 9 & Lingkungan (X4) & (X4D) & -0.621 & 0.002 & Negatif \\
\hline
\end{tabular}

Hambatan budaya merupakan hambatan dalam proses komunikasi yang dilihat dari dimensi individualistikkolektivistik. Dimensi ini merupakan suatu dimensi utama keragaman budaya yang digunakan untuk menjelaskan perbedaan dan kesamaan dalam komunikasi antar partisipan yang memiliki perbedaan latar belakang budaya. Berdasarkan Tabel 3, variabel hambatan individualistik (X1A) berpengaruh terhadap efektivitas komunikasi secara signifikan dengan arah pengaruh negatif. Hal tersebut menunjukkan bahwa semakin tinggi hambatan individualistik (X1A) yang terjadi di antara partisipan komunikasi, maka semakin rendah efektivitas komunikasi yang terjadi (Y), begitupula sebaliknya. Pengaruh budaya dapat mempengaruhi efektivitas komunikasi antarbudaya dilihat dari sisi individualistik responden terhadap pasangan teman berbeda budayanya, berupa sifat yang masih lebih mendahulukan kepentingan pribadinya dibandingkan kepentingan pasangan temannya sebagai anggota dari suku yang berbeda sehingga masih menimbulkan perasaan canggung dan tersinggung pada beberapa responden.

Hal ini dapat disebabkan kedekatan yang terjalin belum cukup lama, sehingga masing-masing etnis masih mengutamakan kepentingan pribadinya. Sikap inilah yang terkadang dapat memunculkan perasaan canggung untuk mencoba mendekati dan masuk kedalam kehidupan pasangan temannya. Intensitas pertemuan yang tidak terlalu tinggi menjadi faktor pendukung terjadinya hambatan budaya di antara mereka. Terlebih kondisi suku non-Sunda yang terkadang hanya berkumpul dengan sesama sukunya saja, contohnya seperti suku Madura. Hal tersebut membuat suku Sunda merasa canggung jika ingin mencoba bergabung dengan teman suku Madura tersebut. Selain itu, misalnya suku Batak yang cenderung low context yakni dicirikan dengan berkata apa adanya dan terbuka, terkadang menjadi suatu hal yang menyinggung perasaan teman berbeda budayanya. Sebagai contoh yang dirasakan oleh salah satu responden ketika pasangan temannya berkomentar tentang dirinya, berikut penuturan FAS: 
“...dia mah emang cuek sih yah orangnya, jarang juga ngumpul sama kita-kita mah. kalo ngomong suka japlak, pas awal sih tersinggung mana kalau ngomong kayak judes gitu kan, tapi kesininya mah udah biasa aja, nggak usah dimasukin ke hati gitu, itu mah emang dia orangnya seperti itu kan”. (FAS, 26 th, PribumiSunda)

Hal ini didukung oleh hasil penelitian yang dilakukan oleh penelitian yang dilakukan oleh Aksan (2009) tentang komunikasi antarbudaya yang terjadi antara etnis Jawa dan etnis Tionghoa di Solo. Sifat etnis Tionghoa yang mempunyai cara berpikir apabila mereka mempunyai masalah maka tidak perlu meminta pertolongan dari orang lain selama masalah tersebut dapat diselesaikan sendiri. Pemikiran inilah yang mungkin saja menimbulkan persepsi bahwa etnis keturunan Tionghoa merupakan sosok yang individual. Sikap individualistik yang sering melekat di etnik keturunan Tionghoa mungkin saja karena mereka selalu mengerjakan segala sesuatu itu dengan mengandalkan diri sendiri, bukan karena bantuan dari orang lain, sehingga terciptalah sebuah persepsi bahwa etnik Tionghoa merupakan sosok yang individualistik yang akhirnya mempengaruhi komunikasi etnis Jawa dan etnis Tionghoa.

Penelitian lain yang mendukung adanya pengaruh hambatan budaya berupa sifat individualistik terhadap efektivitas komunikasi antar budaya yakni penelitian yang dilakukan oleh Tinambunan (2012). Dari hasil pengamatannya, diperoleh informasi bahwa pada umumnya responden dari suku yang sama tinggal berkelompok dalam suatu daerah tertentu, sehingga muncul nama-nama daerah sesuai dengan daerah asal mereka. Contohnya salah satu nama jalan/gang di daerah Duri Kecamatan Mandau yang diberi nama Gang Toba yang menunjukkan bahwa migran yang bertempat tinggal di daerah itu dominan berasal dari daerah Toba atau Tapanuli, Sumatera Utara. Pengelompokan para migran dalam suatu daerah tertentu akan menghambat proses komunikasi antarbudaya.

\section{Pengaruh Hambatan Sosiobudaya terhadap Efektivitas Komunikasi}

Merujuk pada pendapat Gudykunst dan Kim (1997) bahwa keanggotaan seseorang dalam suatu kelompok dapat mempengaruhi proses komunikasi. Identitas suatu kelompok etnik dapat di perlihatkan dengan penggunaan bahasa yang menjadi ciri khas setiap suku. Perbedaan bahasa sebagai identitas etnik juga dapat menjadi hambatan ketika lawan bicara yang berbeda suku tidak dapat memahami pembicaraan, sehingga pada beberapa kasus membuat lawan bicaranya merasa canggung dan tersinggung.

Hal tersebut terbukti ketika salah satu responden menyatakan bahwa perbedaan bahasa pada suku masingmasing terkadang membuat responden tidak mengerti apa yang sedang dibicarakan, bahkan merasa tersinggung karena merasa sedang menjadi bahan pembicaraan. Kesalahpahaman juga dapat memunculkan rasa canggung karena tidak mengerti apa yang sedang dibicarakan ketika sedang berkumpul dengan orang yang berbeda suku dengannya. Hal tersebut dapat dilihat dari penuturan salah satu responden berikut:

"Kadang suka tersinggung sih kalau lagi kumpul, sesama mereka mah ngomong bahasa Sunda, ngomong apaan sih ini kan, ngomongin kita apa kagak, kita jadi bingung mau bales ngomong apa, paling biar ngademin hati sendiri sih ya ikut iya iya aja, padahal mah kagak ngarti. Iya terus kan jadi canggung juga jadinya, ya kalau kita kagak ngarti mau ngomong apa, apalagi disini kan teteh baru yah, jadi juga belum terlalu tau sifat mereka banget. Jadi kendala yang paling susah sih bahasa, karena sukunya beda kan ya bahasa yang paling susah dipahami." (IWD, 21 th, Pendatang-Betawi)

Hal ini diperkuat oleh salah satu penelitian sebelumnya yang dilakukan oleh Lubis (2012) menyatakan bahwa kesalahpahaman pada komunikasi antarbudaya etnis Tionghoa dan etnis Batak disebabkan oleh penggunaan bahasa ibu sebagai identitas etniknya yang digunakan tidak sesuai dengan situasi dan kondisi yang sedang berlangsung. Hambatan bahasa yang tidak dipahami suku Batak tentang bahasa Hokkian dan Mandarin sebagai ciri identitas etnik Tionghoa menyebabkan terjadinya kesalahpahaman terhadap makna pesan yang disampaikan dan memberikan kesan miring terhadap etnik Tionghoa tersebut, bahkan menimbulkan rasa tersinggung pada etnik Batak selaku suku pribumi, seolah-olah etnik Tionghoa tidak mau ikut berbaur dengan suku pribumi. Padahal hal tersebut dilakukan oleh etnik Tionghoa karena mereka merasa lebih nyaman dan pesan yang disampaikan dapat dipahami. 
Selain itu penelitian sebelumnya yang dilakukan oleh Christy (2013) terkait komunikasi antarbudaya antara dosen native asal China dengan mahasiswa asal Indonesia, hambatan komunikasi terjadi karena penggunaan aksen yang masih melekat dalam pelafalan mahasiswa asal Indonesia yang terbiasa menggunakan bahasa Indonesia dan logat Jawa (Surabaya). Ketika menggunakan bahasa Mandarin di kelas, mahasiswa asal Indonesia tersebut menggunakan bahasa Mandarin dengan menambahkan aksen Surabaya. Hal ini membuat dosen native sulit memahami pesan dan menyandi kembali pesan yang dimaksud oleh mahasiswa.

Akan tetapi di sisi lain, berdasarkan keterangan salah satu informan mengatakan bahwa komunikasi seharihari berjalan efektif walaupun memiliki perbedaan agama. Misalnya orang Batak yang beragama Kristen, walaupun berbeda agama dengannya tetapi tetap menjalin hubungan baik. Kuncinya adalah saling menghormati dan saling menghargai. Misalnya ketika hari raya seperti Lebaran ataupun Natalan, masingmasing saling mengirimkan makanan, sebagai bentuk apresiasi dan bentuk saling menghargai. Kemudian rasa memaklumi kebiasaan suku lain juga membantu untuk mengurangi rasa tersinggung, seperti penuturan informan berikut:

"Orang kan emang beda yah, misalnya agama deh. Biar kata orang Batak ada yang Kristen, kita Islam, kita tetep suka berbagi aja gitu. Ibu mah ngirim-ngirim makanan, dia juga gitu kalau Natal. Kalau ibu mah yah gimana yah, orang Padang, orang Batak gitu pada baik-baik semua ke ibu, nggak ada yang suka nantangin gitu, ya gimana kitanya juga kali sih yah, kalau kitanya ngerti sama sifat mereka mah mungkin ke kitanya juga nggak bakalan sakit hati gitu” (ERN, 52 th, ibu RK)

\section{Pengaruh Hambatan Psikobudaya terhadap Efektivitas Komunikasi}

Berdasarkan Tabel 3, variabel hambatan psikobudaya (variabel X3) berpengaruh terhadap variabel efektivitas komunikasi (variabel Y) dengan arah pengaruh negatif. Hal tersebut menunjukkan bahwa semakin tinggi hambatan psikobudaya (X3) yang terjadi di antara partisipan komunikasi, maka semakin rendah efektivitas komunikasi (Y) yang terjadi, begitupun sebaliknya, semakin rendah hambatan psikobudaya (X3) yang terjadi di antara partisipan komunikasi, maka semakin tinggi efektivitas komunikasinya (Y).

Terdapat tiga dimensi dari hambatan psikobudaya, yakni stereotype, etnosentrisme, dan prasangka. Berdasarkan hasil uji statistik yang disajikan pada pada Tabel 3, jika diurutkan dari koefisien terbesar hingga terkecil pada variabel bebas $\mathrm{X} 3 \mathrm{~A}, \mathrm{X} 3 \mathrm{~B}$, dan $\mathrm{X} 3 \mathrm{C}$ adalah koefisien variabel X3A (stereotype) dengan nilai koefisien -0.862 , X3B (etnosentrisme) dengan nilai koefisien -0.674 , kemudian diikuti X3C (prasangka) dengan nilai koefisien -0.587 .

Hal ini terbukti ketika stereotype sempat dirasakan oleh salah satu responden terhadap pasangan temannya dari suku Batak. Suku Batak yang dianggapnya sebagai sosok yang berbicara apa adanya dan galak, membuat FAS (suku Sunda) merasa canggung untuk memulai pembicaraan, bertukar pendapat, bahkan pernah merasa tersinggung karena ucapan orang Batak yang mengatakan bahwa orang Sunda adalah pemalas, seperti penuturannya berikut:

"Tapi kadang kalo ngomong suka to the point apa adanya mbak, pernah waktu itu saya kan sempet keluar dari kerjaan, terus kali dia ngeliat saya di rumah terus, eh dia malah bilang saya katanya cari pekerjaan lah jangan pemalas jadi pengangguran. Mungkin maksudnya ngingetin sih cuma pas itu kaget aja dia ngomongnya begitu, logatnya juga kan keras da' jadi bikin saya makin tersinggung”. (FAS, 26th, PribumiSunda)

Hal ini didukung oleh hasil penelitian sebelumnya yang dilakukan oleh Iswari dan Pawito (2012), yang menyatakan bahwa hambatan stereotype merupakan salah satu hambatan yang mempengaruhi proses komunikasi antar mahasiswa yang memiliki perbedaan latar belakang budaya. Stereotype yang terjadi yakni karena terdapat image tentang orang Batak bahwa orang Batak adalah orang yang galak dan kasar, sehingga hal tersebut mempengaruhi komunikasi antarbudaya dengan mahasiswa lain yang berbeda etnis dengan mereka. 
Selain itu, penelitian Astuti (2014) menyatakan bahwa sikap stereotype yang sering kali nampak ketika seseorang menilai orang lain pada kelompok etnis tertentu, dan selanjutnya menjadi label yang menempel pada penilaian pribadi individu tersebut, dan akhirnya akan mempengaruhi cara individu tersebut dalam berkomunikasi dengan lawan bicaranya yang telah ter-stereotype-kan tersebut.

\section{Pengaruh Hambatan Lingkungan terhadap Efektivitas Komunikasi Antarbudaya}

Berdasarkan Tabel 3, variabel hambatan lingkungan (variabel X4) berpengaruh terhadap variabel efektivitas komunikasi (variabel Y) dengan arah pengaruh negatif. Hal tersebut menunjukkan bahwa semakin tinggi hambatan lingkungan (X4) yang terjadi di antara partisipan komunikasi, maka semakin rendah efektivitas komunikasi (Y) yang terjadi, begitupun sebaliknya.

Terdapat empat dimensi dari hambatan lingkungan (X4), yakni lingkungan fisik (X4A), situasi (X4B), situational norms and rules (X4C), dan lingkungan psikologi (X4D). Berdasarkan hasil uji statistik pada Tabel 3 jika diurutkan dari koefisien terbesar hingga terkecil pada variabel bebas X4A, X4D, dan X4B adalah koefisien variabel X4A (lingkungan fisik) dengan nilai koefisien -0.676, X4D (lingkungan psikologi) dengan nilai koefisien -0.621, kemudian X4B (situasi) dengan nilai koefisien -0.422 . Variabel situational norms and rules (X4C) memiliki nilai koefisien 0.229, sehingga dapat dikatakan variabel X4C, tidak berpengaruh terhadap efektivitas komunikasi.

Pengaruh keadaan lingkungan terbukti mempengaruhi cara berkomunikasi responden kepada pasangan temannya yang berbeda budaya yakni ketika suku non-Sunda yang berasal dari Sumatera berbicara lantang karena memang terbentuk dari kondisi geografis di tempat awalnya antar satu rumah dengan rumah lain berjauhan. Namun ketika berbicara dengan warga suku Sunda yang tidak terbiasa, maka akan merasa tersinggung dan merasa sedang berada dalam kondisi yang tidak nyaman, sehingga menimbulkan kesalahpahaman dan berujung pada rasa canggung.

Selain itu, rasa canggung juga dirasakan oleh salah satu responden karena pintu rumah pasangan temannya dari suku Madura yang selalu tertutup. Hal ini membuat responden menjadi canggung jika ingin berkunjung ke rumah temannya karena merasa bahwa temannya memang tidak ingin menerima tamu. Akan tetapi, orang Sunda tersebut memahami bahwa orang Madura memang pulang pada malam hari untuk istirahat, karena esok paginya harus kembali bekerja, sehingga dapat diatasi dengan saling mengerti kondisi masingmasing. Hal serupa terjadi pada penelitian yang dilakukan oleh Juariah (2014) yang menyatakan bahwa hambatan lingkungan psikologi yang terbentuk dari persepsi individu atas kondisi lingkungan dapat mempengaruhi komunikasi antarbudaya. Mahasiswa asal Bekasi merasa tersinggung ketika sedang berbicara dengan mahasiswa asal Madura yang berbicara dengan nada keras seperti orang yang sedang marah, sehingga membuat mahasiswa asal Bekasi merasa kesal dan emosi. Padahal, mahasiswa asal Madura memang sudah terbiasa bersuara lantang akibat kondisi lingkungan di tempat asalnya merupakan wilayah pesisir dan membuatnya harus berbicara dengan volume suara yang keras.

\section{Hambatan Budaya, Psikobudaya, dan Hambatan Lingkungan secara Bersamaan Mempengaruhi Efektivitas Komunikasi}

Dari tabel Anova pada Tabel 2 menunjukkan bahwa nilai $\mathrm{F}=101.561$ dengan nilai Sig. $=0.000$ lebih kecil dari 0.05 yang menunjukkan bahwa hambatan budaya (X1), psikobudaya (X3), dan hambatan lingkungan (X4) secara bersamaan mempengaruhi efektivitas komunikasi antarbudaya (Y) secara signifikan dan negatif. Hal ini berarti semakin tinggi hambatan budaya, psikobudaya, dan lingkungan maka diikuti dengan rendahnya efektivitas komunikasi antarbudaya.

Hambatan psikobudaya yang berpengaruh paling signifikan adalah stereotype. Hal tersebut dapat terjadi karena masing-masing suku memiliki ciri khas sukunya, sedangkan stereotype merupakan kognisi seseorang terhadap ciri negatif yang melekat suatu kelompok yang digeneralisasikan kepada seluruh anggota dari kelompok tersebut dapat dengan mudah menyinggung orang tersebut dan memicu munculnya 
konflik. Hal ini didukung oleh pernyataan Darmastuti (2013) mengenai stereotype, yakni suatu pandangan negatif yang seringkali ditempelkan kepada suatu masyarakat sebagai stempel yang harus melekat tanpa melihat perubahan yang terjadi di dalam masyarakat itu. Bahkan tidak jarang stempel negatif ini juga dilekatkan kepada semua anggota yang ada dari suatu masyarakat atau komunitas yang akan mempengaruhi proses komunikasi, bahkan memicu konflik.

Samovar et al. (2010) juga menyatakan bahwa stereotype dapat menjadi masalah ketika menempatkan orang di tempat yang salah. Stereotype dapat mengganggu kelancaran komunikasi antarbudaya. Contohnya seperti adanya stereotype mengenai orang Padang, bahwa orang Padang itu pelit. Melalui stereotype itu maka indvidu akan memperlakukan semua orang Padang seperti orang yang pelit tanpa memandang pribadi dan keunikan masing-masing individu.

\section{KESIMPULAN DAN SARAN}

Efektivitas komunikasi antabudaya yang terjadi antara suku Sunda dan non-Sunda (Jawa, Madura, Batak, Minangkabau, Betawi) dalam kehidupan bertetangga di Desa Tanjungbaru sudah cukup tinggi walaupun belum maksimum karena masih terdapat hambatan komunikasi antarbudaya. Tingginya efektivitas komunikasi menunjukkan bahwa dampak negatif keberagaman tidak terjadi karena keberagaman budaya yang dimiliki masing-masing suku sudah dapat terorganisir. Hambatan komunikasi antarbudaya masih dapat diatasi, terutama kesadaran para etnis non-Sunda sebagai pendatang yang harus beradaptasi. Rasa toleransi, menghormati, dan menghargai satu sama lain juga sudah mulai terjalin pada proses interaksi untuk menghindari perasaan canggung dan tersinggung, sehingga dampak negatif keberagaman budaya seperti konflik antarsuku tidak terjadi di Desa Tanjungbaru.

Merujuk pada klasifikasi hambatan komunikasi antarbudaya bahwa di Desa Tanjungbaru hambatan komunikasi antarbudaya pada kasus pasangan pertemanan berbeda budaya antara suku Sunda dan nonSunda yang paling tinggi adalah hambatan budaya (individualistik). Hal ini terjadi karena warga suku Sunda atau non-Sunda yang merupakan pendatang (memiliki kepentingan dan orientasi masing-masing, sesuai dengan tujuan awal datang yakni untuk mencari pekerjaan). Hal tersebut menjadikan intensitas pertemuan mereka yang tidak dapat setiap hari berinteraksi untuk menghabiskan waktu bersama dalam menjalin kedekatan. Kedekatan yang belum terjalin lama dapat menjadi salah satu alasan mengapa terkadang rasa canggung untuk menyapa, memulai pembicaraan, atau bahkan bertukar pendapat dapat muncul. Akan tetapi, kondisi kepadatan penduduk di desa tersebut sangat memungkinkan mereka berinteraksi karena jarak dari satu rumah ke rumah/kontrakan lain tidak terlampau jauh.

Berdasarkan uji statistik yang dilakukan, hambatan komunikasi yang dapat mempengaruhi efektivitas komunikasi antarbudaya adalah hambatan budaya (individualistik), hambatan psikobudaya (stereotype, etnosentrisme, prasangka), dan hambatan lingkungan (lingkungan fisik, situasi, situational norm and rules, lingkungan psikologi). Selain tiga hambatan tersebut, terdapat pula hambatan sosiobudaya oleh yang terindikasi memiliki pengaruh terhadap efektivitas komunikasi antarbudaya. Berdasarkan seluruh hambatan komunikasi yang dapat mempengaruhi efektivitas komunikasi antarbudaya, didapatkan bahwa yang memiliki hasil paling signifikan secara berurutan adalah hambatan psikobudaya, hambatan budaya, dan hambatan lingkungan. Dimensi dari hambatan psikobudaya yang paling mempengaruhi adalah stereotype. Hal ini dapat terjadi karena kognisi seseorang terhadap ciri negatif yang melekat pada suatu kelompok, yang digeneralisasikan kepada seluruh anggota dari kelompok yang dapat memunculkan rasa canggung, bahkan menyinggung seluruh anggota dari kelompok tersebut. Selain itu, stereotype juga merupakan sejenis penyaring, menyediakan informasi yang konsisten dengan informasi yang dipercayai oleh seseorang, sehingga suatu hal yang benar tidak akan memiliki kesempatan untuk diketahui.

\section{Saran}

Berdasarkan kesimpulan terkait dengan hambatan komunikasi antarbudaya yang masih terjadi, maka saran yang diajukan untuk akademisi adalah mengkaji lebih dalam terkait dengan masing-masing subvariabel 
hambatan. Mengkaji hambatan sosiobudaya secara kuantitatif karena terindikasi memiliki pengaruh terhadap efektivitas komunikasi antarbudaya.

Berdasarkan kesimpulan terkait dengan pengaruh hambatan komunikasi antarbudaya, maka saran yang diajukan untuk masyarakat yakni membuat suatu agenda yang memfasilitasi warga dengan berbagai suku agar dapat berinteraksi dan mengenal lebih dekat agar hambatan-hambatan komunikasi antarbudaya dapat diminimalisasi karena memiliki kesadaran mengenai pentingnya komunikasi antarbudaya.

Berdasarkan kesimpulan terkait dengan stereotype sebagai hambatan paling berpengaruh, maka saran yang diajukan untuk masyarakat adalah bersikap mindful (kesadaran dalam berkomunikasi terkait siapa teman bicaranya), saling mendekatkan diri dan bergaul, aktif berpartisipasi kegiatan kampung, menggunakan bahasa dan istilah yang dimengerti satu sama lain, bersikap terbuka, saling menghormati dan menghindari berpikir negatif untuk meningkatkan kepercayaan.

\section{DAFTAR PUSTAKA}

Aksan EE. 2009. Komunikasi antarbudaya etnik Jawa dan etnik keturunan Cina. J Komunikasi [Internet]. [dikutip 2 Maret 2014]; 7(1): 1-15. Dapat diunduh dari: http://jurnal.upnyk.ac.id/ index.php/komunikasi/article/viewFile/6/34

Anugrah D, Kresnowati W. 2008. Komunikasi Antar Budaya: Konsep dan Aplikasinya. Jakarta (ID): Jala Permata. 188 hal.

Astuti P. 2014 Komunikasi sebagai sarana akulturasi antara kaum urban dengan masyarakat urban dengan masyarakat lokal di Pasar Segiri. E-J Komunikasi [Internet]. [dikutip 9 Maret 2014]; 2(1): 305-320. Dapat diunduh dari: http://ejournal.ilkom. fisip-unmul.ac.id/ site/wpcontent/uploads/ 2014/02/ejournal\%20puji\%20(02-25-14-06-33-03).pdf

Azis M. 2010. Efektivitas komunikasi antar etnis: kasus etnis Arab dan etnis Sunda di Kelurahan Empang, Bogor Selatan) [skripsi]. Bogor (ID): Institut Pertanian Bogor. 72 hal.

[BPS] Badan Pusat Statistik. 2010. Sensus Penduduk Indonesia Tahun 2010. Jakarta (ID): BPS

Christy MP. 2013. Hambatan komunikasi antarbudaya antara dosen native asal China dengan mahasiswa Indonesia program studi Satra Tionghoa Universitas Kristen Petra. J E-Komunikasi [Internet]. [dikutip 20 Februari 2014]; 1(2): 37-48. Dapat diunduh dari: http://studentjournal.petra.ac.id/ index. php/ilmu-komunikasi/ article/view/891

Darmastuti R. 2013. Mindfullnessdalam Komunikasi Antarbudaya. Yogyakarta (ID): Mata Padi Pressindo. 296 hal.

Devito JA. 2009. Human Communication: The Basic Course. Edisi ke-11. New York (US): Pearson Education

2011. Komunikasi Antar Manusia. Edisi ke-5. (Alih bahasa dari bahasa Inggris oleh Maulana A). Pamulang (ID): Karisma Publishing Group. 600 hal.

Gudykunst WB, Kim YY. 1997. Communicating with strangers: An Approach to Interculture Communication. Edisi ke-3. New York (US): McGraw-Hill. 444 hal.

Iswari AN, Pawito. 2012. Komunikasi antarbudaya di kalangan mahasiswa (Studi tentang komunikasi antarbudaya di kalangan mahasiswa etnis Batak dengan mahasiswa etnis Jawa di Universitas Sebelas Maret Surakarta). J Komunikasi Massa [Internet]. [dikutip 5 Maret 2014]; 1: 1-13. Dapat diunduh dari: http://jurnalkommas.com/index.php?target=isi\&jurnal=Komunikasi $\% 20$ Antar\%20Budaya $\% 20$ di $\% 20$ Kalangan $\%$ 20Mahasiswa\% 20(\%20Studi\%20tentang\%20Komunikasi\%20Antar\%20Budaya\%20\%20di\%20Kala ngan $\% 20$ Mahasiswa\%20Etnis\%20Batak\%20dengan $\% 20$ Mahasiswa\%20etnis\%20\%20Jawa\%20di $\% 2$ 0Universitas\%20Sebelas\%20\%20Maret\%20Surakarta\%20

Lubis LA. 2012. Komunikasi antarbudaya Tionghoa dalam penggunaan bahasa. J Ilmu Komunikasi [Internet]. [dikutip 2 Maret 2014]; 10(3): 285-294. Dapat diunduh dari: http://jurnal.upnyk.ac.id/index.php/ komunikasi/article/viewFile/46/50 
Muhidin SA, Abdurahman M. 2007. Analisis Korelasi, Regresi, dan Jalur dalam Penelitian. Bandung (ID): CV Pustaka Setia. 280 hal.

Pakpahan FB. 2013. Fungsi komunikasi antarbudaya dalam prosesipernikahan adat Batak di Kota Samarinda (Studi kasus empat pasanganberbeda etnis antara etnis Batak dengan etnis Jawa, Toraja, dan Dayak). E-J Ilmu Komunikasi [Internet]. [dikutip 21 Februari 2014]; 1(3): 234-248. Dapat diunduh dari:http://ejournal.ilkom.

fisip-unmul.ac.id/site/wp-content/uploads/ 2013/08/jurnal\%20jadi\%20(08-26-13-03-35-36).pdf

Sanjaya A. 2013. Hambatan komunikasi antarbudaya antara staf marketing dengan penghuni berkewarganegaraan Australia dan Korea Selatan di Apartemen X. J E-Komunikasi [Internet]. [dikutip 20 Februari 2014]; 1(3): 252-263. Dapat diunduh dari: http://studentjournal.petra.ac.id/ index.php/ ilmu-komunikasi/article/view/939/839

Samovar LA, Porter RE, McDaniel ER. 2010. Komunikasi Lintas Budaya. Edisi ke-7. (Alih bahasa dari bahasa Inggris oleh Sidabalok IM). Jakarta (ID): Salemba Humanika. 493 hal. [Judul asli: Communication Between Cultures].

Sihabudin A. 2013. Komunikasi Antarbudaya: Satu Perspektif Multidimensi. Jakarta (ID): Bumi Aksara. 162 hal.

Singarimbun M, Effendi S. 1989. Metode Penelitian Survei. Jakarta (ID): LP3ES

Tinambunan WE. 2012. Dampak migrasi terhadap komunikasi lintas budaya. JIlmuKom. [Internet]. [dikutip 21 Februari 2014]; 1(1): 43-49. Dapat diunduh dari: http://ejournal. unri.ac.id/index.php/JKMS/article/view/609

Tubbs SL, Moss S. 2008. Human Communication. New York (US): McGraw-Hill. 